\title{
ANALISIS KARAKTERISTIK PEMBAKARAN LANGSUNG (Co- COMBUSTION) ARANG KAYU DAN DAUN CENGKEH SISA DESTILASI MINYAK ATSIRI DENGAN VARIASI KOMPOSISI
}

\author{
Abdul Basyid Adnan, Subroto, Sartono Putro \\ Teknik Mesin Universitas Muhammadiyah Surakarta \\ Jl. A. Yani Tromol Pos I Pabelan, Kartasura \\ Email:subroto@ums.id
}

\begin{abstract}
ABSTRAK
Limbah proses destilasi (penyulingan) minyak atsiri daun cengkeh yang berupa daun cengkeh kering sering dianggap sebagai limbah industri dan kurang diperhatikan manfaatnya. Diperkirakan saat ini penggunaan daun cengkeh kering sisa proses destilasi minyak atsiri hanya digunakan sebagai pendukung dari pembakaran proses penyulingan tersebut. Oleh karena itu penting adanya penelitian untuk mengurangi polusi yang ditimbulkan oleh limbah tersebut,diantaranya dengan menjadikan daun cengkeh kering sisa proses sebagai bahan dasar biomassa. Penelitian diawali dengan pengumpulan bahan dasar berupa daun cengkeh sisa proses destilasi daun cengkeh dan arang kayu kemudian dihancurkan dan selanjutnya dicampur dengan variasi komposisi yang berbeda. Variasi yang digunakan adalah variasi komposisi, yaitu 100\% arang kayu, 100\% daun cengkeh, $80 \%$ arang kayu dan 20\% daun cengkeh, 60\% arang kayu dan 40\% daun cengkeh, 40\% arang kayu dan 60\% daun cengkeh. Pengujian karakteristik pembakaran dilaksanakan untuk mengetahui karakteristik temperatur pembakaran, massa sisa dan laju pembakaran yang dihasilkan oleh campuran arang kayu dan daun cengkeh. Pengujian ini dilakukan pada sebuah tungku pembakaran dan pengambilan data dilakukan setiap 1 menit. Hasil penelitian menunjukkan bahwa variasi komposisi berpengaruh pada karakteristik pembakaran.Penambahan arang kayu akan mempertinggi temperatur pembakaran dan memperlama waktu pembakaran.Waktu pembakaran paling baik dimiliki biomassa dengan komposisi $60 \%$ arang kayu dan $40 \%$ daun cengkeh dengan temperatur $268^{\circ} \mathrm{C}$ pada menit ke-6 dan massa sisanyayakni 0,71 gram.
\end{abstract}

Kata kunci: Arang Kayu, Daun Cengkeh, Biomassa

\section{ABSTRACT}

Waste from distillation of essential oils of clove leaves in the form of dried clove leaves is often regarded as industrial waste and its benefits are usually neglected.. Currently, it is estimated that the use of dried clove leaves is only as a support to the combustion process of the distillation process. Therefore, it is important to reduce the pollution caused by these wastes, for example making dry clove leaves as a biomass base material. Thisstudy begins with the collection of basic ingredients in the form of clove leaves which are the remainder of the clove leaves distillation process and wood charcoal. Then, they are crushed and mixed with a variety of different compositions. Variations used are variations in composition, namely $100 \%$ wood charcoal, $100 \%$ clove leaves, $80 \%$ wood charcoal and 
$20 \%$ clove leaves, $60 \%$ wood charcoal and $40 \%$ clove leaves, $40 \%$ wood charcoal and $60 \%$ clove leaves. Testing of combustion characteristics is carried out to determine the characteristics of combustion temperature, residual mass and combustion rate produced by a mixture of wood charcoal and clove leaves. This test is carried out on a furnace and data collection is carried out every 1 minute. The results shows that the variation in composition affects the characteristics of combustion. Wood charcoal addition increases the combustion temperature and prolong the combustion time. The fastest combustion time is produced by biomass with a composition of $60 \%$ wood charcoal and $40 \%$ clove leaves with a temperature of $268^{\circ} \mathrm{C}$ with six minutes and the remaining mass is 0.71 grams.

\section{Keywords: Wood Charcoal, Clove Leaves, Biomass}

\section{PENDAHULUAN}

Indonesia merupakan penghasil sejumlah minyak atsiri.kebanyakan minyak atsiri tersebut ekspor atau dijual keluar negeri. Sementara itu banyak pengusaha atau industri yang belum dapat memanfaatkan sisa limbah menjadi sebuah produk yang mempunyai nilai ekonomis tinggi. Sisa limbah hasil industri dapat dimanfaatkan sebagai sumber energi alternatif baru bisa berasal dari fosil, biomassa, limbah ,dansebagainya,

Sentra minyak cengkeh di Musuk, Boyolali banyak menggunakan bahan bakar daun kering sisa proses destilasi yang merupakan sisa dari proses penyulingan minyak astiri untuk proses produksinya.

Masalah yang timbul adalah bagaimana memanfaatkan daun kering sisa proses, dan bagaimana mengurangi polusi yang ditimbukkan pada waktu pembuangan limbah yang berupa daun cengkeh sisa destilasi. Diperkirakan sampai saat ini penggunaan daun kering sisa proses hanya digunakan sebagai pendukung dari bahan-bakar proses tersebut.

Melihat permasalahan diatas maka akan lebih baik jika limbah tersebut dijadikan biomassa (campuran daun cengkeh kering limbah proses destilasi minyak atsiri dan arang kayu) agar lebih berguna dan bermanfaat sebagai bahan bakar alternatif baru.

\section{BATASAN MASALAH}

Dalam makalah ini masalah yang diteliti adalah analisis karakteristik pembakaran biomassa (campuran daun kering limbah proses destilasi minyak cengkeh dan arang kayu) berupa laju pembakaran, penurunan massa dan hubungan temperatur dengan laju pembakaran dengan variasi komposisi 100\% daun cengkeh, 100\% arang, arang kayu dicampur dengan daun cengkeh dengan perbandingan komposisi 80\%:20\%, 60\%:40\%, 40\%:60\%. Binder yang digunakan adalah aspal, dengan komposisi 10\% dari berat total setiap briket.

\section{TUJUAN PENELITIAN}

Tujuan penelitian ini untuk mengetahui karakteristik pembakaran dari biomassa(campuran daun kering limbah proses destilasi minyak cengkeh dan arang kayu) yang berupa temperatur pembakaran, massa sisa pembakaran, laju pembakaran.

\section{TINJAUAN PUSTAKA}

Joko (2005) melakukan penelitian tentang karakteristik pembakaran biobriket campuran ampas aren dengan arang kayu sebagai bahan bakar alternatif [1]. Yang menghasilkan bahwa semakin banyak kandungan ampas aren akan memperbesar laju pengurangan massa pada saat terjadi proses pembakaran, ini dikarenakan ampas aren mengandung nilai volatile metter yang 
lebih besar dari pada arang kayu dimana kandungan ini bersifat mudah terbakar. Bila semakin banyak kandungan arang kayu (dalam satu satuan berat) akan semakin besar pula temperatur yang dihasilkan, hal ini dikarenakan arang kayu mempunyai nilai kalor yang lebih tinggi dari pada ampas aren

Andrew (2005) melakukan penelitian mengenai karakteristik pembakaran briket campuran arang kayu dan sekam padi dengan tiga kali variasi campuran [2]. Dalam penelitian tersebut dijelaskan bahwa laju pembakaran biobriket paling cepat adalah pada komposisi 50\% sekam padi : 50\% arang kayu. Hal ini dipengaruhi oleh kandungan volatile matter. Semakin banyak kandungan volatile matter suatu biobriket maka semakin mudah biobriket tersebut terbakar, sehingga pembakaran semakin cepat.

\section{DASAR TEORI}

Menurut Gautara (1980), arang adalah bahan bakar padat yang berpori-pori dan merupakan hasil pembakaran dari bahan yang mengandung unsur karbon (C). sebagian pori-porinya masih tertutup hidrokarbon, dan senyawa organik lain yang komponennya terdiri dari "fixet carbon", abu, air, nitrogen,dan sulfur [3]. Adapunsifat-sifat yang dimilikiolehbahanbakarpadatadalahsebagaiberikut :

1. KandunganZat-zat yang MudahMenguap (Volatile Matter).

Kandungan volatile matter pada suatu arang kayu menunjukkan tingkat kualitas arang kayu tersebut. Semakin tinggi kandungan volatile matter maka semakin rendah kualitas arang kayu. Karena tingginya kandungan volatile matter akan lebih mempercepat pembakaran dan banyak menimbulkan asap.

2. TemperaturPencetusan (Flashing Temperature)

Adalah temperatur dimana bahan bakar terbakar akan terbakar dengan sendirinya oleh udara sekelilingnya disertai percikan api sebagai pemicu nyala.

3. TemperaturPenyalaan (Ignition Temperature)

Adalah suhu pada saat bahan bakar akan mulai terbakar setelah mengeluarkan zat-zat penguapnya.

4. Kecepatan Pembakaran

Bahan bakar padat dalam pembakarannya sangat dipengaruhi oleh proses penguapan kadar air dan volatile matter yang terkandung dalam bahan bakar tersebut. Hal inilah yang menjadi faktor utama dalam kecepatan pembakaran.

5. Ukuran Arang Kayu

Ukuran partikel arang kayu itu sendiri juga akan mempengaruhi besarnya panas yang dihasilkan dalam pembakaran. Hal ini disebabkan semakin besar partikel-partikel penyusun arang kayu maka akan mengakibatkan rongga antar partikel akan menjadi lebih besar sehingga akan menurunkan nilai kalor yang dihasilkan mempengaruhi kecepatan pembakaran. Semakin kecil partikelnya maka akan semakin cepat laju pembakarannya.

6. Kecenderungan untuk Menggumpal

Dalam bahan bakar padat masih banyak terdapat kadar air, sehingga apabila bahan bakar disimpan dalam waktu yang relatif lama maka akan mengakibatkan bahan bakar akan mudah untuk lunak dan saling menggumpal antara partikel satu dengan yang lain akibatnya celah antar partikel yang berfungsi untuk tempat aliran udara akan tertutup sehingga memperlambat proses penguapanpada proses pembakaran.

Adapun beberapa tahapan dalam pembakaran bahan bakar padat tersebut adalah sebagai berikut :

1. Pengeringan 
Merupakan tahap awal daripada proses pembakaran bahan bakar padat. Dalam proses ini bahan bakar mengalami kenaikan temperatur yang mengakibatkan menguapnya kadar air yang berada pada permukaan bahan bakar itu sedangkan untuk kadar air yang berada di dalam akan menguap melalui pori-pori bahan bakar padat tersebut.

2. Devolatisasi

Yaitu proses bahan bakar mulai mengalami dekomposisi setelah terjadi pengeringan. Proses dekomposisi merupakan peristiwa pecahnya ikatan kimia secara termal dan volatile matter (merupakan hasil proses devolatilisasi) keluar dari partikel. Proses devolatilisasi berlangsung cepat dan memerlukan $20-30 \%$ dari seluruh waktu pembakaran diluar penyalaan.

3. PembakaranArang

Tahap akhir dari proses pembakaran bahan bakar padat adalah pembakaran arang. Aranginimerupakanhasil sisa daiprosesdevolatilisasi yang telahsempurna dan juga terdapatabu.

\section{METODE PENELITIAN \\ Diagram AlirPenelitian}

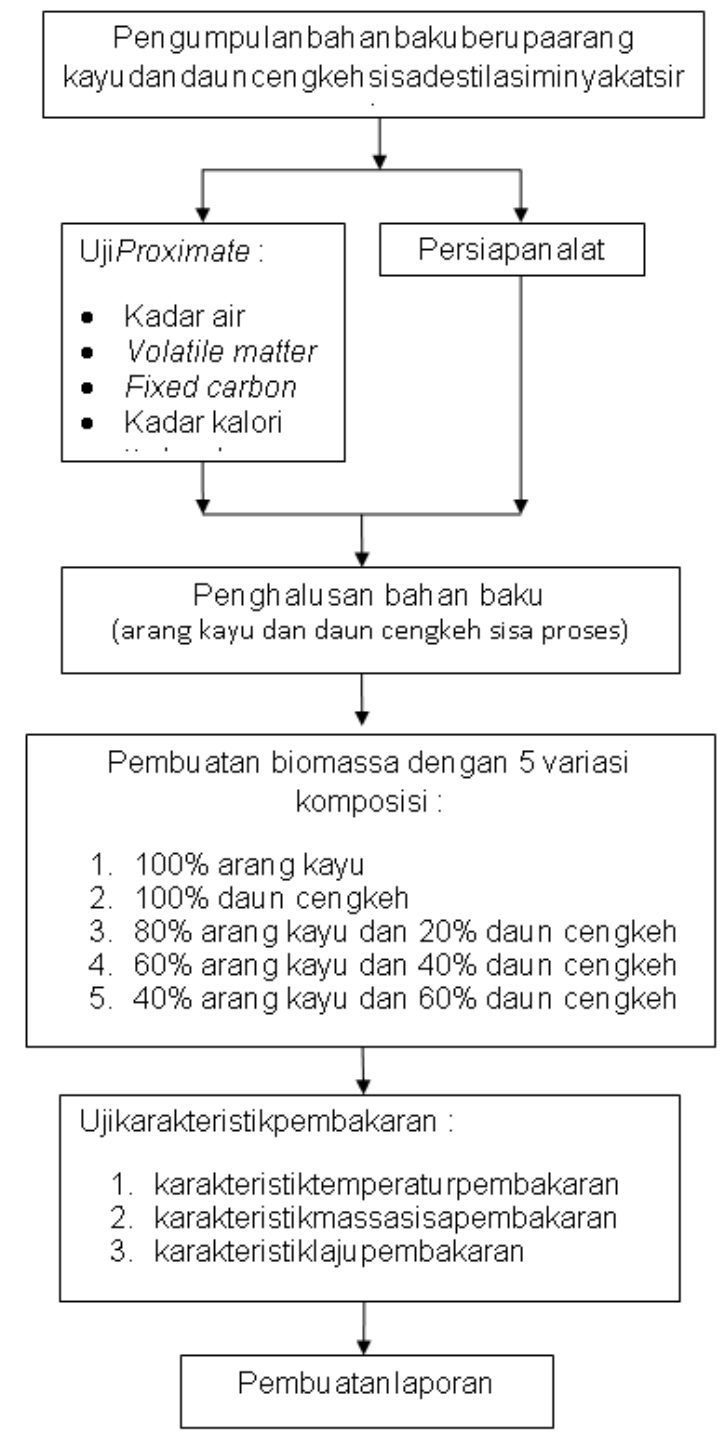

Gambar 1. Diagram AlirPenelitian 


\section{BahanPenelitian}

Bahan-bahan yang digunakan dalam penelitian ini adalah arang kayu dan daun cengkeh (sisa proses destilasi).

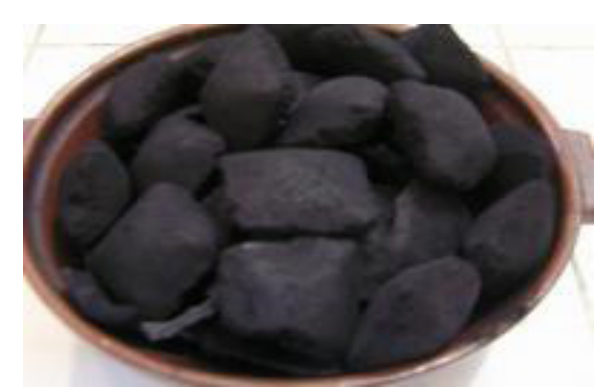

(a)

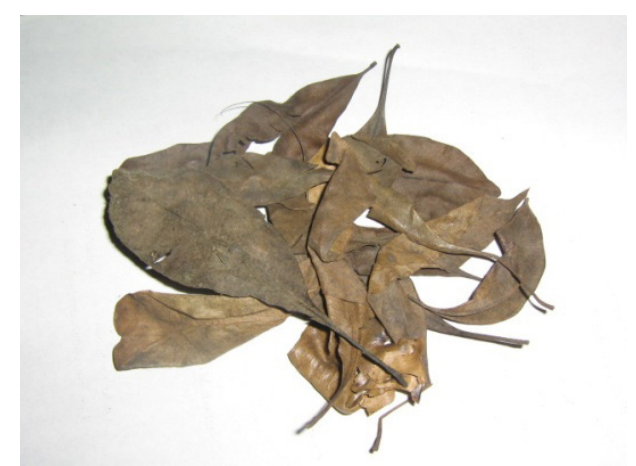

(b)

Gambar 2. Bahan-bahanpenelitian, (a)arang kayu and (b)dauncengkeh

\section{PenghalusanBahan Baku}

Dalam hal ini yang perlu dihaluskan adalah batu bara dan daun cengkeh sisa proses.

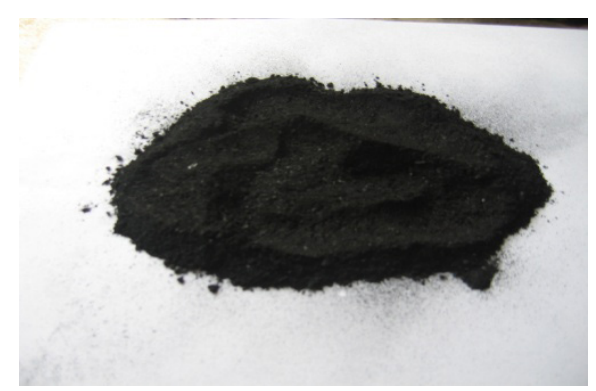

Gambar 3. arang kayu yang telah dihaluskan.

Gambar 4. Daun cengkeh yang telah dihaluskan 


\section{Alat-alat Penelitian}

Alat-alat yang digunakan dalam penelitian ini adalah:

1. Alat penghalus daun cengkeh (blender)

2. Timbangan digital

3. Alat pengepres

4. Tungkupembakaran

5. Stopwatch

6. Thermocouple dan thermocouple reader

7. Anemometer

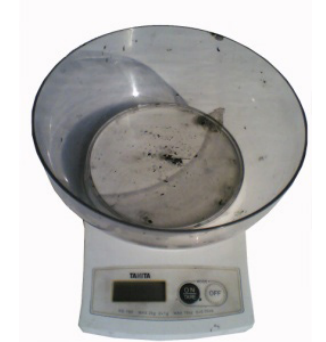

Gambar 5. Timbangan digital

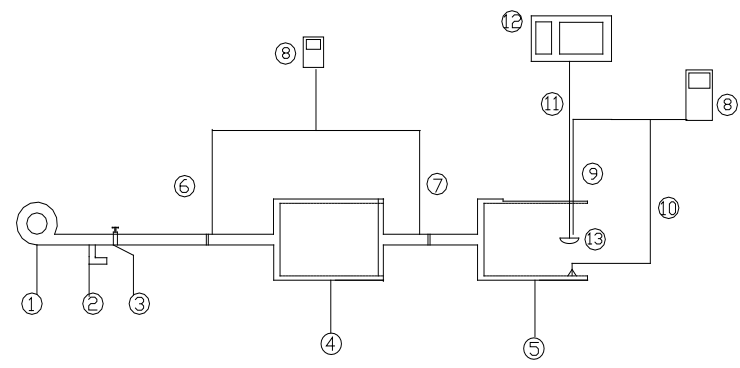

Gambar 6. Skema alat uji karakteristik pembakaran

Keterangan:

1. Blower

2. Saluran by pass

3. Katup pengatur aliran udara

4. Tungku 1

5. Tungku 2

6. Termokopel temperatur uadara

7. Termokopel temperatur udara pre-heater

8. Digital termocouple reader

9. Termokopel temperatur briket

10. Termokopel temperatur dinding

11. Kawat ke timbangan digital

12. electronik profesional scale (timbangan digital 


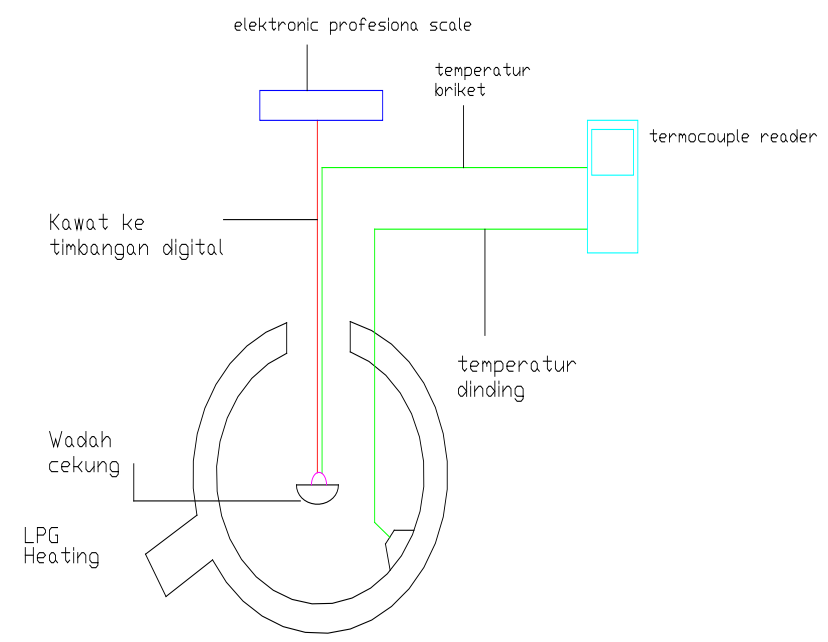

Gambar 7. Skema tabung pembakaran

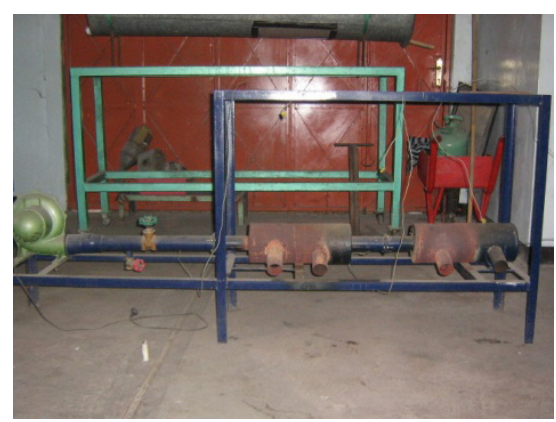

Gambar 8. Alattungkupembakaran

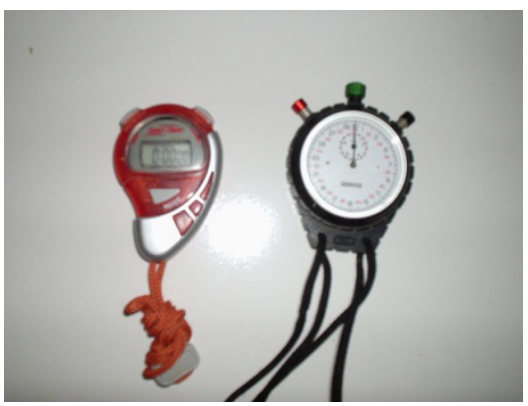

Gambar 9. Stop wacth

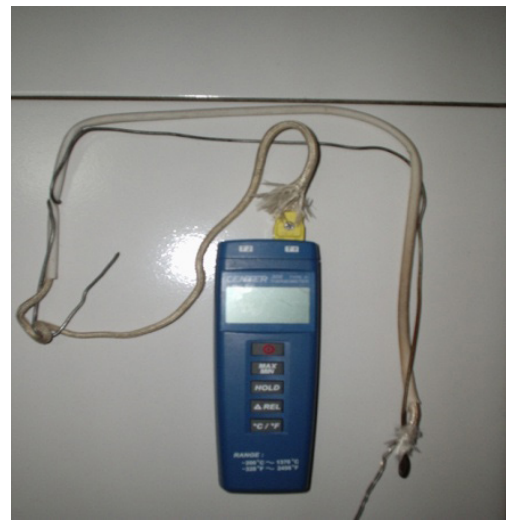

Gambar 10. Termocoupel dan Termocopel reader 


\section{Analisis Proximate Bahan Baku}

Bahan baku kemudian diuji secara proximate. Pengujian ini dilakukan di Pusat Studi Pangan dan Gizi serta Laboratoriun Kimia Analitik Universitas Gadjah Mada.

Analisis proximate merupakan analisis untuk memperkirakan kinerja bahan bakar pada saat pemanasan dan pembakaran. Analisis proximate biasa digunakan untuk menganalisa kadar air, zatterbang (volatile matter), kadar abu, dan kadar kalori.

\section{Pembuatan Biomassa}

Biomassa dibuat dengan perbandingan komposisi 100\% arang kayu,100\% daun cengkeh, $80 \%$ arang kayu : 20\% daun cengkeh, $60 \%$ arang kayu : 40\% daun cengkeh, dan $40 \%$ arang kayu : $60 \%$ daun cengkeh. Biomassa dibuat dengan berat 5 gram.

\section{Uji Karakteristik Pembakaran}

Pengujian Pembakaran bertujuan untuk mengetahui karakteristik pembakaran biomassa. Pengujian ini dilakukan pada sebuah tungku pembakaran. Pengambilan data dilakukan setiap 1 menit. Data penelitian yang dicatat adalah laju pembakaran, pengurangan massa dan temperatur pembakarannya.

\section{HASIL DAN PEMBAHASAN}

\section{Hasil Pengujian Kandungan Bahan Dasar}

Tabel 1. Data Kandungan Bahan Dasar

\begin{tabular}{ccc}
\hline Kandungan & Arangkayu & Dauncengkeh \\
\hline $\begin{array}{c}\text { Volatilematter }(\%) \\
\text { Fixedcarbon } \\
(\%)\end{array}$ & 10.7302 & 46.0091 \\
$\begin{array}{c}\text { Kadar air } \\
(\%)\end{array}$ & 60.8027 & 13.0309 \\
$\begin{array}{c}\text { Kadarabu } \\
(\%)\end{array}$ & 11.27 & 9.925 \\
$\begin{array}{c}\text { Kadarkalori (kal/ } \\
\text { kg) }\end{array}$ & 6650.2055 & 6089.199 \\
\hline
\end{tabular}

Dari tabel di atas menunjukkan bahwa kelebihan dari Daun cengkeh adalah kandungan volatile matter dan kadar kalori yang cukup tinggi mencapai $46.0091 \%$ untuk volatile matter dan $4089.199 \mathrm{kal} / \mathrm{kg}$ untuk kadar kalorinya, kandungan volatile matter yang tinggi akan mempermudah penyalaan dan kadar kalori yang tinggi akan menyebabkan temperatur pembakaran yang tinggi. Sedangkan kadar abu dari arang kayu lebih tinggi dari daun cengkeh yaitu mencapai $25.9 \%$, kandungan kadar abu akan berpengaruh dalam lamanya proses pembakaran.

\section{Hasil Pengujian Pembakaran}

Pada Gambar 11 pembakaran biomassa dengan komposisi 100\% daun cengkeh menghasilkan temperaturtertinggi pada temperatur $239^{\circ} \mathrm{C}$ pada menit ke-3, biomassa dengan komposisi $40 \%$ arang kayu dan $60 \%$ daun cengkeh menghasilkan temperatur tertinggi pada temperatur $260^{\circ} \mathrm{C}$ pada menit ke-5, biomassa dengan komposisi $60 \%$ arang kayu dan $40 \%$ daun 
cengkeh mampu menghasilkan temperatur tertinggi pada temperatur $268^{\circ} \mathrm{C}$ pada menit ke-6, biomassa dengan komposisi $80 \%$ arang kayu dan 20\% daun cengkeh mampu menghasilkan temperatur tertinggi pada temperatur $275^{\circ} \mathrm{C}$ pada menit ke- 8 dan temperatur tertinggi dihasilkan oleh biomassa dengan komposisi $100 \%$ arang kayu pada temperatur $295^{\circ} \mathrm{C}$ pada menit ke- 12 . Perbedaan pencapaian temperatur tertinggi pada tiap biomassa berbeda, ini disebabkan oleh laju pembakaran yang berbeda dari tiap komposisi biomassa.

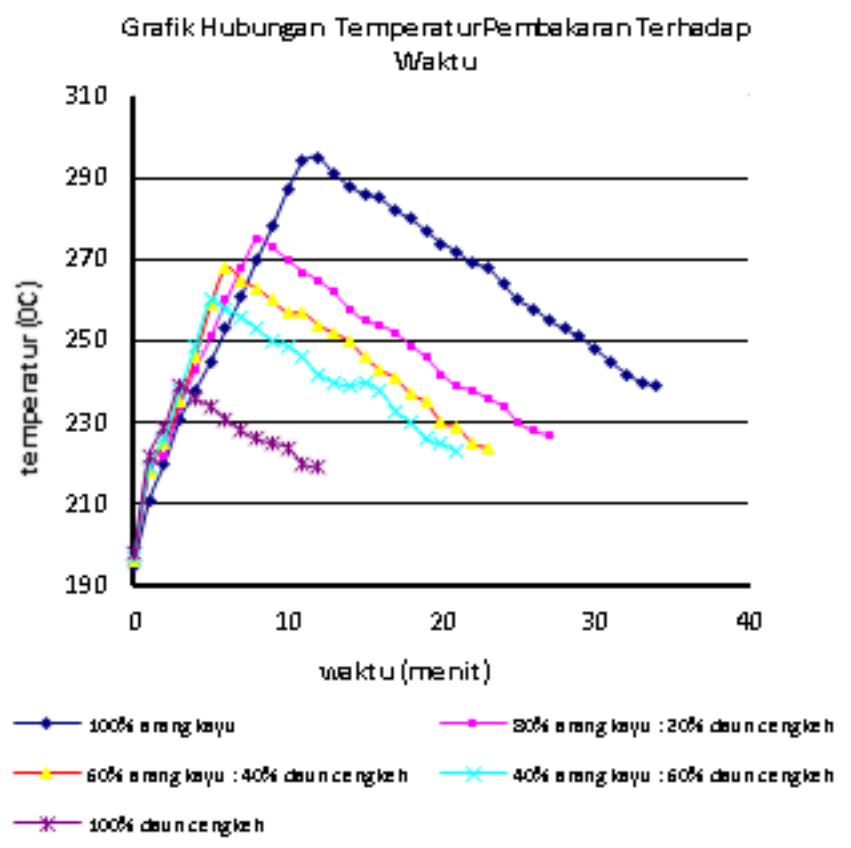

\section{Gambar 11. Grafik hubungan antara Temperatur Pembakaran terhadap waktu}

Semakin banyak campuran arang kayu dalam komposisi biomassa maka akan menyebabkan semakin tingginya temperatur pembakaran yang dihasilkan. Hal ini dikarenakan dengan semakin banyaknya kadar arang kayu dalam bioiomassa, maka kandungan kalori biomassa juga akan semakin besar, begitu pula sebaliknya semakin sedikit campuran arang kayu dalam biomassa maka akan menyebabkan semakin rendahnya temperatur pembakaran yang dihasilkan karena kandungan kalori biomassa semakin kecil, ini terjadi pada biomassa 100\% arang kayu.

Biomassa pada waktu pembakaran nol menit mempunyai massa yang sama sebesar 5 gram. Pada pembakaran terlihat adanya gejala pengurangan massa yang berbeda antara komposisi satu dengan yang lain. Semakin lama waktu pembakaran maka semakin jelas adanya perbedaan pengurangan massa.

Terlihat bahwa biomassa dengan komposisi 100\% arang kayu mempunyai sisa massa 0,8 pada menit ke-34, biomassa komposisi $80 \%$ arang kayu dan $20 \%$ daun cengkeh mempunyai sisa massa 0,78 pada menit ke-27, biomassa komposisi $60 \%$ arang kayu dan $40 \%$ daun cengkeh mempunyai sisa massa 0,75 pada menit ke-23, biomassa komposisi $40 \%$ arang kayu dan $60 \%$ daun cengkeh mempunyai sisa massa 0,74 pada menit ke-21, sedangkan untuk biomassa yang sisa massanya paling sedikit yaitu biomassa komposisi 100\% daun cengkeh dengan sisa massa 0,71 pada menit ke-12. 


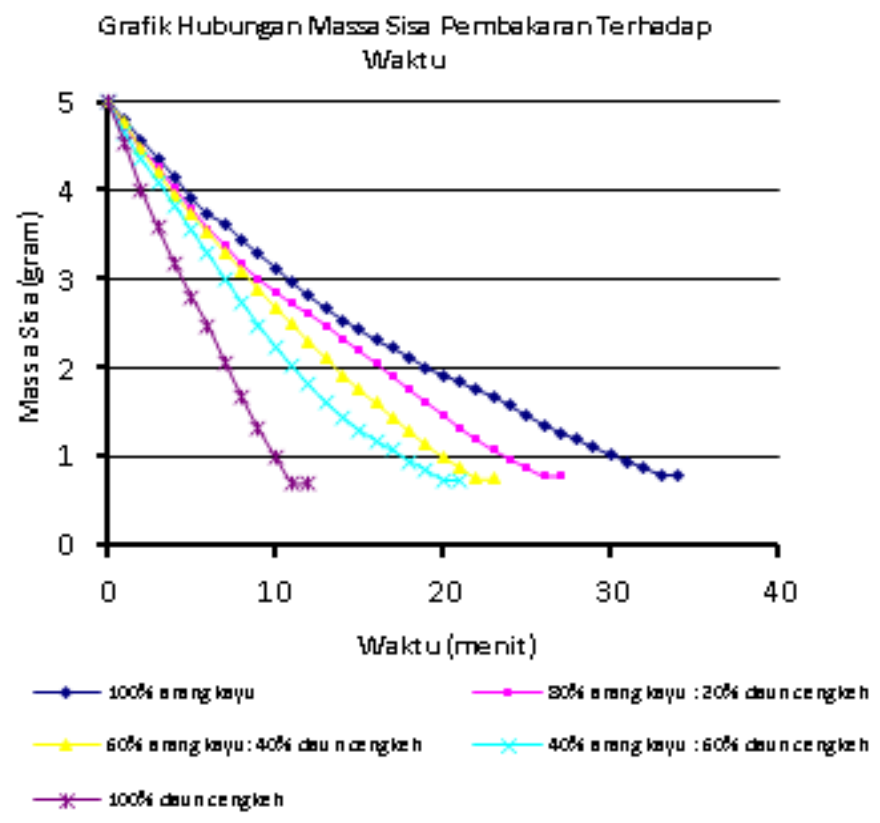

Gambar 12. Grafik hubungan antara massa sisa Pembakaran terhadap waktu

Semakin banyak kandungan arang kayu dalam komposisi biomassa maka semakin banyak sisa pembakarannya atau abu yang terbentuk dalam biomassa dan sebaliknya semakin sedikit daun cengkeh maka akan semakin sedikit abu yang terbentuk. Hal ini disebabkan adanya pengaruh kadar abu yang terkandung dalam arang kayu dan daun cengkeh. Dimana kadar abu pada arang kayu lebih besar daripada daun cengkeh (lihat tabel 1).

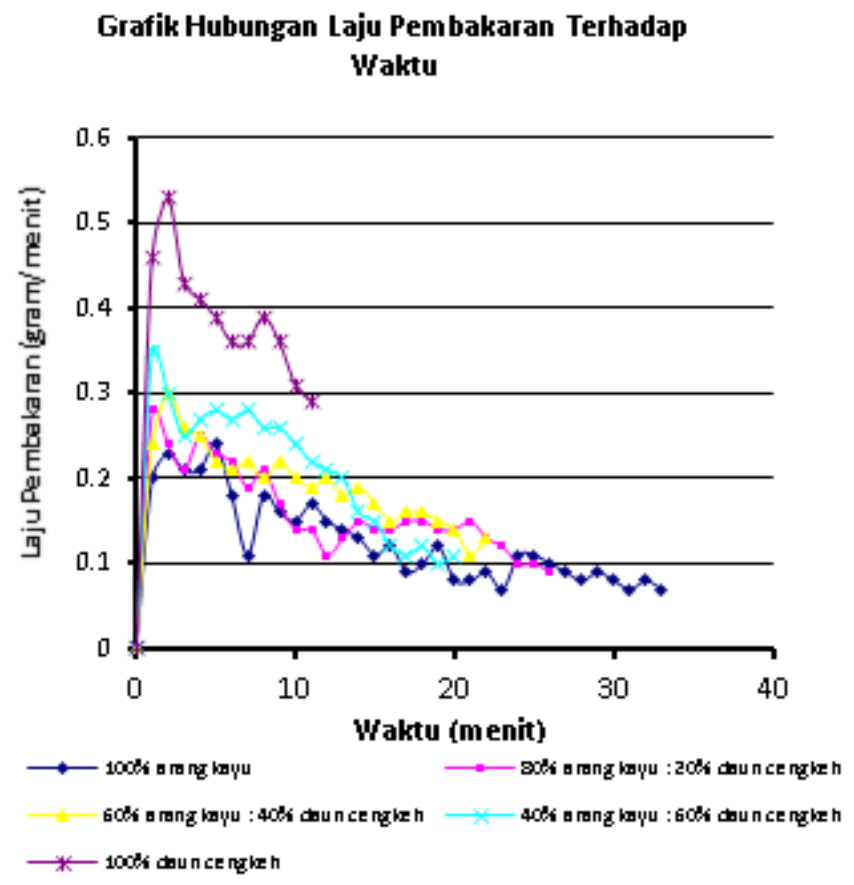

Gambar 13. Grafik hubungan antara laju Pembakaran terhadap waktu

Setelah mengetahui dan menganalisis hubungan pengurangan massa biomassa terhadap waktu, selanjutnya dapat dilakukan perhitungan laju pembakaran. Gambar 13 menunjukkan 
pengaruh komposisi biomassa terhadap laju pembakaran. Dasar dari perhitungan laju pembakaran adalah data massa sisa itu sendiri.

Dari pembacaan Gambar 13 didapatkan informasi bahwa biomassa dengan komposisi $100 \%$ daun cengkeh mempunyai laju pembakaran tertinggi sebesar $0,53 \mathrm{gram} / \mathrm{menit}$ pada menit ke-2, biomassa dengan komposisi 40\% arang kayu dan 60\% daun cengkeh mempunyai laju pembakaran tertinggi sebesar 0,35 gram/menit pada menit ke-1, biomassa dengan komposisi $60 \%$ arang kayu dan $40 \%$ daun cengkeh mempunyai laju pembakaran tertinggi sebesar 0,3 gram/menit pada menit ke-2 ,dan biomassa dengan komposisi $80 \%$ arang kayu dan $20 \%$ daun cengkeh mempunyai laju pembakaran tertinggi sebesar 0,28 gram $/$ menit pada menit ke- 2 , dan biomassa dengan komposisi $100 \%$ arang kayu mendapatkan laju pembakaran tertinggi sebesar 0,23 pada menit ke -2 .

Waktu yang dibutuhkan biomassa dalam mencapai laju pembakaran tertingginya berbedabeda. Laju pembakaran dipengaruhi oleh sifat dasar dari daun cengkeh yang mudah terbakar, semakin banyak massa yang terbakar laju pembakarannya akan semakin tinggi. Dimana nilai volatile matter yang tinggi akan mempermudah proses pembakaran biomassa.Dengan naiknya kadar arang kayu dalam biomassa maka kadar fixed karbon akan semakin meningkat sehingga biomassa akan sulit terbakar dan memakan waktu yang cukup lama untuk proses pembakarannya.

Untuk komposisi 100\% arang kayu laju penurunan massanya paling lama yakni,pada menit ke-5 denganlaju pembakaran dari 0,24 gram/menit menjadi 0,11 gram/menitpada menit ke-7. Hal ini disebabkan tingginya nilai karbon terikat (fixed carbon) yang dimiliki oleh arang kayu. Ini berakibat proses pembakarannya memakan waktu yang agak lama. Secara garis besar karakteristik pembakaran biomassa tergantung dari komposisi biomassa yang dibakar, semakin banyak campuran arang kayu maka semakin lama waktu pembakaran. Sedangkan apabila semakin sedikit campuran arang kayu maka akan semakin cepat dalam proses pembakarannya.

\section{KESIMPULAN}

1. Semakin banyak campuran arang kayu dalam komposisi penyusunan, maka kandungan kalori dalam komposisi juga semakin besar serta dapat menyebabkan semakin tingginya temperatur dalam komposisi biomassa.ini terjadi pada komposisi $80 \%$ arang kayu dan $20 \%$ daun cengkeh dengan temperatur $275^{\circ} \mathrm{C}$ pada menit ke-8.

2. Semakin tingginya kandungan arang kayu dalam komposisi ,maka sisa pembakaran atau abu yang terbentuk juga semakin banyak .ini terjadi pada komposisi $80 \%$ arang kayu dan $20 \%$ daun cengkeh dengan massa sisa 0,78 gram pada menit ke- 27 .

3. Semakin banyak kandungan volatile matter dalam komposisi pembakaran maka akan menyebabkan laju pembakaran semakin singkat ,dikarenakan kandungan volatile matter daun cengkeh lebih banyak dari padaarang kayu. Ini terjadi pada komposisi $60 \%$ daun cengkeh dan $40 \%$ arang kayu dengan laju pembakaran 0,53 gram/menit pada menit ke- 1 .

\section{DAFTAR PUSTAKA}

[1] Purwanto. J, 2005, ” Karakteristik Pembakaran Biobriket Campuran Ampas Aren Dengan Arang Kayu Sebagai Bahan Bakar Alternatif ”, Tugas Akhir, FT UMS.

[2] Andrew, 2005, "Karakteristik pembakaran briket campuran arang kayu dan sekam padi dengan tiga kali variasi campuran", Tugas Akhir, FT UMS.

[3] Gautara, 1980, "Petunjuk Praktek Pengolahan Hasil Pertanian 3” Depdikbud. Jakarta 